DOI https://doi.org/10.18551/rjoas.2018-10.04

\title{
ANALYSIS OF CUSTOMER PREFERENCES IN SELECTING FUNDING PRODUCTS AT BANK: SAVINGS, GIRO AND DEPOSITS
}

\author{
Raysharie Puput Iswandyah*, Santoso Dwi Budi, Manzilati Asfi \\ Faculty of Economics and Business, University of Brawijaya, Indonesia \\ ${ }^{*}$ E-mail: puput.iraysharie@gmail.com
}

\begin{abstract}
This study aims to determine the influence of external factors of the marketing mix in the form of products, prices, place, promotions, service processes, people, as well as the physical evidence of customer decisions in choosing banking products offered. The research was conducted at hotels, inns, and villas in Batu City, East Java. Quantitative research method accidental sampling techniques were applied to determine the sample. The number of samples was 85 respondents. Binary logistic regression analysis in SPSS 16 was performed to analyze the obtained data. The results showed that there were significant effects of marketing mix variables (products, prices, places, and processes) on customers' considerations of selecting banking products (savings, giro, deposits). Other marketing mix variables (promotion, people, and physical form) do not have a significant effect on the decision to choose the use of banking products.
\end{abstract}

\section{Key words}

Marketing mix, customer decision, funding products, bank.

Banks are financial institutions that have an important role in supporting economic growth. As an intermediary institution, namely collecting funds from third parties and channeling them in the form of credit, making the bank as one of the sources of development funds. The national banking system consists of two types, which are conventional (using the interest system as payment for equity participation) and sharia (using profit-sharing as payment for equity participation).

Sharia banks have the same growth opportunities as conventional banks in Indonesia, although the number of accounts in Sharia banks is relatively lower than in conventional banks. This is shown in Figure 1, where there a raised of account in Sharia banks from 2010 to 2015 despite the fact that it is still below the conventional bank. The graph illustrated customer preferences in choosing to save in Sharia banks still exist over the time although still below the conventional banks.

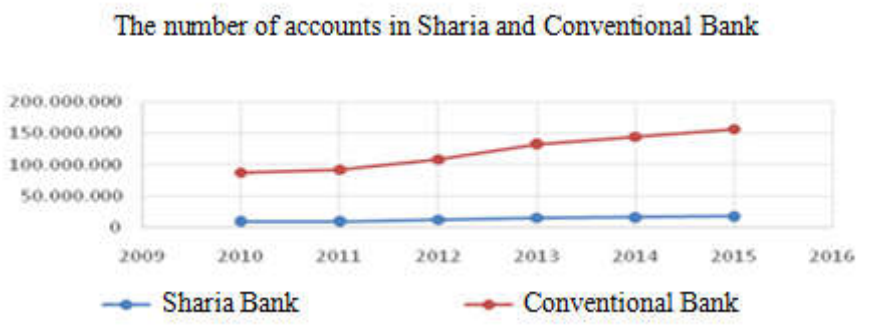

Figure 1 - The number of accounts in Sharia and Conventional Bank (Source: Deposit Insurance Agency)

Banking service customers are not just individuals, but banks as financial management services also handle customers in the form of institutions and companies. One of the fastest growing companies in Indonesia is a company or industry engaged in the tourism sector. According to data from the Central Bureau of Statistics (BPS) the growth of tourism in Indonesia in 2015 was 7.2 percent or above the world tourism growth of 4.4 percent. One industry that needs attention is the hospitality industry, recorded in BPS data that a number 
of 16,156 hotel businesses in Indonesia are calculated in 2015. East Java Province has the most number of hotel businesses, namely 2091 hotel businesses, with a total number of domestic and foreign guest visits. 23,578 during 2015 (Central Bureau of Statistics/BPS). The data shows that East Java has the most income in the hotel business sector compared to other provinces in Indonesia.

Batu City, East Java, as one of the main tourist destination for both domestic and foreign tourists, according to BPS Batu City has the second highest number of hotels after Pasuruan, it was 440 hotel businesses in 2014 (jatim.bps.go.id, 2014). This opportunity could motivate the banking services to attract customers from the hospitality industry in Batu City, with the hope of being able to increase the number of third-party funds (DPK) as the main funding source in banking services. Based on the data above, conventional and Sharia banking have the opportunity to earn trust from hospitality companies in Batu City in using banking products. Zulpahmi (2010) cited in Yupitri and Sari (2012) describes the factors that influence customers in using Sharia banking services in the absence of interest (usury), the attitude and behavior of employees who are friendly and polite, the security of customer funds, the interesting and innovative variety, easily accessible and strategic location. According to Sutisna (2002), purchasing decisions are decisions by consumers to purchase a product beginning with the existence of the fulfillment of needs and desires. In order for the management to get to know the customer and understand the customer's wishes now and in the future. Good and excellent service is expected to be provided by the bank to create customer loyalty.

Research conducted by Selim \& Rahman (2015) states that conventional marketing strategies satisfy customers based on the customer's current needs. Whereas Sharia marketing strategies satisfy customers based on human values, marketing culture, and Sharia rules and regulations (sharia law). From several previous studies, there is a research gap that discusses customer preferences in the conventional bank or Sharia bank product selection. Therefore, this study was conducted to determine the influence of external factors in the form of products, prices, locations, promotions, service processes, people, and physical evidence of the customer's decision in choosing to use the banking products offered.

\section{LITERATURE REVIEW}

Consumer Behavior. Consumer behavior is the act of individuals or groups in selecting and buying an item or service to satisfy their needs (Solomon, 2002). Whereas according to Amirullah (2002), consumer behavior is a number of real actions of individuals (consumers) that are influenced by reasonableness (psychological) factors and other external factors (external) that direct them to choose and use the desired items. Consumer behavior models can be interpreted as a framework or something that represents what consumers believe in making buying decisions (Mangkunegara, 2002). In general, the purchase process begins long before the actual and has consequences long after purchase (Kotler in Sumarni, 2002). Kotler et al., (2000) also argue that the stages in the buying process need recognition, information retrieval, alternative evaluation, purchasing decisions, and behavior after purchase

Consumer Preference. Customer preference is the attitude of customers who want an item or service based on the ability to provide satisfaction with what is purchased or offered so that people who want goods or services have an attitude of buying behavior (Marwan, 1990). Salvatore (2006) says that consumer preferences can be deduced from a number of sufficient observations of choices or purchases in the market, without investigating individual preferences directly.

According to Kotler (2002), the marketing mix is a set of marketing tools that companies apply to continuously achieve their marketing goals in the target market. Payne (1993) states that the marketing mix consists of product, place, price, promotion, people, process, provision of consumer service. According to Collier (1991) states the service marketing mix consists of product, price, place, promotion, people (personal traits), physical 
evidence, and process. Some studies show customer preferences in banking product selection. Research by Al Ajmi et al., (2009) states that Islamic bank customers choose products because they are more familiar with products or services in accordance with sharia. Research by Oke (2012) shows that the effect of product development, price of service, promotional activities, and place and channel of distribution of banking on bank performance is significant. Research by Kaura (2013) shows that in price justice banking, transparency services, distribution of banking services in an easy way, employee behavior, customer education, tangibility, and processes through technology play an important role in differentiating services from competitors.

Research by Shamsudin and Rahman (2014) explains that sharia banking could compete in the market and at the same time can improve the level of trust between Muslim customers to buy Halal goods and services. Similarly, conventional banks must consider applying the concept of Islamic marketing rather than conventional if they really want to meet the needs, desires, and desires of Muslim buyers. Research by Islam and Rahman (2015) show that products, prices, and promotions have a significant effect on bank marketing performance, while locations and promotions have no significant effect on bank marketing performance. Research by Roy and Khan (2015) states that there are five variables from the service marketing mix, namely product, price, promotion, process and physical evidence that influence consumer perceptions to give decisions in the selection of savings product. Research by Ahmed and Rahman (2015) found that the marketing mix (price, product, place, and promotion) while upholding and adhering to the rules and regulations in the Quran and Sunnah must maximize and prioritize "customer satisfaction" beyond "profit".

Customer preference in the banking world refers to what values are captured by customers regarding products and how these values can affect the customer's point of view in seeing a product from a service company in this case banking services. The company's internal environment variables are known as 4P consist of product, price, promotion, place, and distribution channel. Oke (2012) in his research stated that banks are likened to a product type of banking so that the variables that influence customer preferences to use a banking product, especially banking products are the marketing mix of goods, products, prices, promotions, places and channels distribution. Likewise with research conducted by Ateba et al., (2015), where in this study the service mix used was the marketing mix of goods namely products, prices, promotions, places and distribution channels so that here the banking products are considered goods rather than services. In contrast the study with Islam and Rahman (2015) where in addition to using products, prices, promotions, places and distribution channels with added environmental variables in the service company that distinguishes the way of delivering services (known as 3P), that are employee services, processes, and physical evidence and characteristics of the service provider bank.

Based on the theoretical foundation and previous research, the following hypothesis can be formulated:

- $\mathrm{H}_{1}$ : Products have a significant effect on customer decisions in using funding products at bank;

- $\mathrm{H}_{2}$ : Price has a significant effect on customer decisions in using funding products at bank;

- $\mathrm{H}_{3}$ : Place have a significant effect on customer decisions in using funding products at bank;

- $\mathrm{H}_{4}$ : Promotion has a significant effect on customer decisions in using funding products at bank;

- $\mathrm{H}_{5}$ : People (employee) have a significant effect on customer decisions in using funding products at bank;

- $\mathrm{H}_{6}$ : Process has a significant effect on customer decisions in using funding products at bank;

- $\mathrm{H}_{7}$ : Physical evidence has a significant effect on customer decisions in using funding products at bank. 


\section{METHODS OF RESEARCH}

The type of research used in this study is descriptive and causality. The approach used in this study is a quantitative approach that is a research method that seeks to quantify data and usually applies certain statistical analyzes (Malhotra, 2010). The location of the study was conducted in Batu City. The population of this study is all hotels, inns and villas are 550 in Batu City which become customers of banking services both conventional banks or Sharia banks. The sample was taken by accidental sampling technique using the Slovin formula (Sevilla \& Ochave 1960) so that 85 respondents were obtained.

Refer to the research objectives, the variables taken include: (1) the dependent variable is the consideration of the customer choosing funding product offerings, and (2) the independent variable is a marketing mix variable that influences consumer decision making, namely product, price, place, promotion, people, process, and physical evidence. Weighting on each variable using a five-level scale (likert scale) consisting of strongly agree, agree, doubt, disagree, and strongly disagree. Based on the calculation of Pearson's product moment correlation index with a significance level of $5 \%$, all items in the question item of the customer preference variable are valid. Similarly, the reliability test uses Alpha Cronbach which shows all reliable question items.

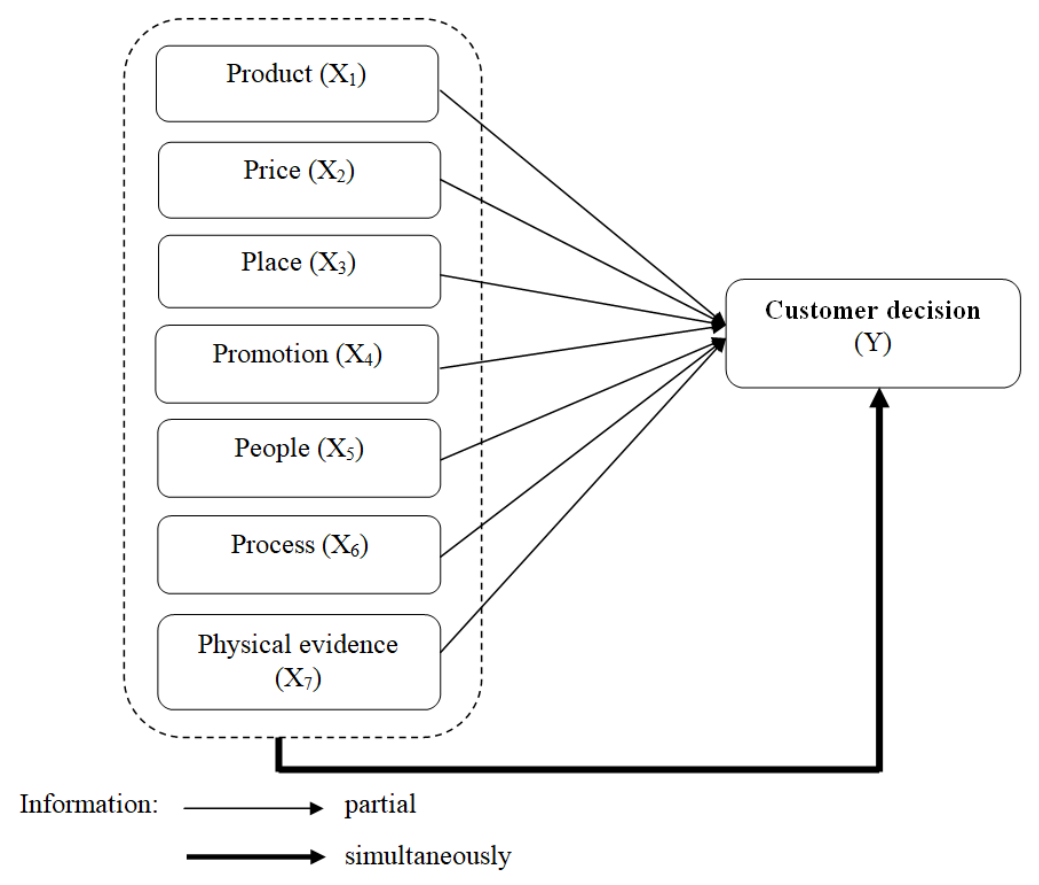

Figure 2 - Research framework

This study uses logistic regression to determine the effect of the independent variable on the dependent variable with the condition that the value of the dependent variable is 0 and 1 (binary). The model used in logistic regression analysis is Logit (pi) $=\beta_{0}+\beta_{1}{ }^{*} X$ with logit (pi) is the value of logit transformation for the probability of success events, $\beta_{0}$ is the intercept of regression line model, $\beta_{1}$ is the slope of regression line model, and $\mathrm{X}$ is an explanatory variable. The following is an estimation of the logistic regression model (Nachrowi \& Usman, 2002):

$$
\mathrm{Li}=\ln \left[\frac{p}{1-p}\right]=\beta_{0}+\beta_{1} X_{1}+\beta_{2} X_{2}+\beta_{3} X_{3}+\cdots+\beta_{k} X_{k}
$$

Thus, the estimated models used in this study are:

$$
\mathrm{Li}=\ln \left[\frac{p}{1-p}\right]=\beta_{0}+\beta_{1} X_{1}+\beta_{2} X_{2}+\beta_{3} X_{3}+\beta_{4} X_{4}+\beta_{5} X_{5}+\beta_{6} X_{6}+\beta_{7} X_{7}
$$


Where:

$\mathrm{Li}=\ln \left[\frac{p}{1-p}\right]$ : preferences of customer decisions in choosing products funding at bank (savings, giro, deposits);

X1: Product;

$\mathrm{X} 2$ : Price;

X3: Place;

X4: Promotion;

X5: People;

X6: Process;

X7: Physical Evidence.

\section{RESULTS AND DISCUSSION}

Model feasibility testing was carried out using a comparison of -2 log likelihood, Omnibus test, Hosmer and Lemeshow test.

Table 1 - Result of Comparisan -2 Log Likelihood

\begin{tabular}{lll}
\hline-2 Log Likelihood & & Negelkerke $\mathrm{R}^{2}$ \\
\hline Block 0 & Block 1 & \\
\hline Constants & Constants + Independent variable & 0,798 \\
\hline 97,210 & 30,461 & \\
\hline
\end{tabular}

Source: binary logistic regression analysis in SPSS 16.

The value of -2 log likelihood in the model involving independent variables $(30,461)$ smaller than the model without involving the independent variable $(97,210)$ shows that the addition of the independent variables in the regression model is better than without the independent variables so that the model used is feasible.

Table 2 - Results of Omnibus Test

\begin{tabular}{llll}
\hline $\mathrm{X}^{2}$ statistic & Significance & $\mathrm{X}^{2}$ table $(7,5 \%)$ & Information \\
\hline 66,749 & 0,000 & 12,592 & Influence \\
\hline
\end{tabular}

Source: SPSS 16.

The calculated Chi-Square value obtained is 66,749 with a significance value of 0,000 . Because the Chi-Square value is greater than the Chi-Square table $(66.749>12.592)$ and the significance value is smaller than alpha $5 \%(0.000<0.050)$, it can be concluded that the model involving independent variables is better and can be used in model or it can be said that there is a real influence simultaneously or together.

Table 3 - Results of Hosmer and Lemeshow Test

\begin{tabular}{llll}
\hline $\mathrm{X}^{2}$ statistic & Significance & $\mathrm{X}^{2}$ table $(7,5 \%)$ & Information \\
\hline 5,200 & 0,636 & 12,592 & Not significant \\
\hline
\end{tabular}

Source: SPSS 16.

The calculated Chi square value obtained was 5,200 with a significance value of 0.636 . Because the Chi square value is smaller than the Chi square table value $(5.200<12.592)$ and the significance value is greater than alpha $5 \%(0.636>0.050)$, it can be concluded that the model used has a predictive probability equal to the observed probability or model those formed are able to predict observation data well and the model is feasible for use.

After conducting a feasibility test on the model, the next step is to test the hypothesis using the basic chi square where if the Wald variable value is greater than the chi square value or the significance value is smaller than alpha $5 \%$ then it can be said that there is a real influence of the independent variable to the dependent variable. 
Table 4 - Results of Hypothesis Testing

\begin{tabular}{llllll}
\hline Variable & Coefficient B & Exp (B) & Wald & Sig & Conclusion \\
\hline X1 & 0,669 & 1,952 & 9,063 & 0,003 & Significant \\
X2 & 1,197 & 3,311 & 7,471 & 0,006 & Significant \\
X3 & 0,425 & 1,530 & 4,972 & 0,026 & Significant \\
X4 & 0,120 & 1,128 & 0,159 & 0,690 & Not Significant \\
X5 & 0,199 & 1,220 & 1,198 & 0,274 & Not Significant \\
X6 & 0,589 & 1,802 & 7,592 & 0,006 & Significant \\
X7 & 0,076 & 1,079 & 0,272 & 0,602 & Not Significant \\
Constant & $-44,764$ & 0,000 & 8,098 & 0,002 & \\
\hline
\end{tabular}

The logistic regression equation that is formed is as follows:

$$
L_{n}=\left(\frac{p}{1+p}\right)=-33,935+0,669 \times 1+1,197 \times 2+0,425 \times 3+0,120 \times 4+0,199 \times 5+0,589 \times 6+0,076 \times 7
$$

Product $\left(X_{1}\right)$ variable has Wald value $(9,063)$ greater than the Chi-Square value $(3,841)$ and significance $(0,003)$ smaller than alpha $5 \%(0,050)$, so it can be said that product variable (X1) will have a significant effect on selecting decisions of banking products. The results of this study are in accordance with the research of Roy and Khan (2015) which states that products have a role in influencing consumer preferences, various types of banking products can affect consumer preferences, consumers have different needs and desires and also different motives to make a purchase or product selection. Provision of diverse products allows the meeting point between consumer needs and offers made by banks so that it can influence consumer decisions to use banking products from the bank.

Price $\left(X_{2}\right)$ variable has Wald value $(7,471)$ greater than the Chi-Square value $(3,841)$ and significance $(0,006)$ smaller than alpha $5 \%(0,050)$ so it can be concluded that the price $\left(\mathrm{X}_{2}\right)$ variable has a significant effect of decision in selecting banking products. In the banking world, the price taken when someone decides to use banking products is the administrative costs that must be incurred by consumers and interest or profit sharing offered to consumers. This is seen as an advantage for consumers who become stimulants to use banking products. The results of this study support the research of Oke (2012), Kustiningsih (2014), and Roy and Khan (2015) which explained that prices are one of the external factors that are proven to influence the decision to use banking products.

Place $\left(X_{3}\right)$ variable has Wald value $(4,972)$ smaller than the Chi-Square value $(3,841)$ and significance $(0,026)$ smaller than alpha $5 \%(0,050)$ so it can be said that place variable (X3) has a significant effect on customer decision in selecting banking products. The results of this study are in accordance with research by Kustiningsih (2014) which shows that determining the location of offices along with supporting facilities and infrastructure is very important so that customers can easily reach each of the existing bank locations.

Variable promotion $\left(\mathrm{X}_{4}\right)$ has a Wald value $(0.159)$ smaller than the Chi-Square value (3.841) and significance (0.690) greater than alpha 5\% (0.050) so it can be said that the promotion $\left(\mathrm{X}_{4}\right)$ variable has no significant effect on banking product selection. It can be seen that in Indonesia bank advertisements are mostly only done when sponsoring certain events and the intensity of printed or non-printed is rarely found, both in sharia and conventional banks. This study supports the research of Fajri et al., (2013) which found the only significant process and product variables.

Variable people $\left(X_{5}\right)$ has Wald value $(1,198)$ smaller than the Chi-Square value $(3,841)$ and significance $(0,274)$ greater than alpha $5 \%(0,050)$, so it can be said that people $\left(X_{5}\right)$ variable has no significant effect on the decision in banking products usage. Staff hospitality cannot be felt unless the person has indeed gone to the bank to conduct transactions so that people have less factor in influencing customers' decisions. This is consistent with the research of Roy and Khan (2015) which explained that from seven dimensions of marketing, people are one of the factors that have no significant effect because both Sharia and conventional banks both have standard operating procedures (SOP) about hospitality and 
ways of addressing customers so that there is no difference that can make someone choose one of the two types of banks in product selection.

Variable process $\left(X_{6}\right)$ has a Wald value $(7,592)$ greater than the Chi-Square value $(3,841)$ and significance $(0,022)$ smaller than alpha $5 \%(0,050)$ so it can be said that the process $\left(\mathrm{X}_{6}\right)$ variable has a significant effect on the decision in banking products usage. The service process and also staff knowledge about bank products become an advantage for consumers to choose banking products. Punctuality and speed of service are very crucial factors in the service business. Therefore, service time is a concern for all sharia and conventional banking businesses. Banks with a long service process will tend to be avoided by consumers, especially in the millennium era where banks are required to be as effective as possible to provide services so that consumers are not disappointed with the services provided. This study supports the research of Kaura (2013), Islam \& Rahman (2015), and Roy \& Khan (2015) which prove that the service process of banks in addressing consumers, both in terms of timeliness and ease of process, has an important role in influencing consumer decisions to use banking products at the bank.

Variable physical evidence $\left(\mathrm{X}_{7}\right)$ has a Wald value $(0.272)$ smaller than the Chi-Square value (3.841) and significance (0.602) greater than alpha $5 \%(0.050)$ so it can be said that the physical evidence $\left(X_{7}\right)$ variable does not significantly influence the decision of banking products usage. Physical form cannot be a factor that can distinguish between one bank and another. This is because building standards and designs are only physical forms that can be directly copied or surpassed by other banks. The strongest differentiator in the service business lies in the intangible of the products sold, namely the process, and also the reliability of banking products. This study is in line with research by Islam and Rahman (2015) which states that physical evidence is one of the external factors that have no significant effect.

\section{CONCLUSION}

Based on the results of this study, it was found that there was a significant effect between the marketing mix variables on the customer's consideration in the selection of the use of banking funding products (savings, giro, and deposits), among others: product, price, place and process. Several other marketing mix factors, namely promotion, people, and physical evidence turned out to have no significant effect on the customers consideration in the selecting to uses of banking products.

Based on the results of this study, it was found that the product factor was the most considered by customers in the selection of the use of banking products (savings, giro, and deposits). The consideration of customers in the selection of the use of banking funding products in this study was also seen through the products offered by the bank. Conventional bank products are preferred by consumers because products and banking systems are familiar with consumers, administrative processes are easier when compared to Sharia banks, and the interest or profit sharing offered is far competitive and administrative costs are relatively cheaper.

\section{REFERENCES}

1. Ahmed, S. \& Rahman, Md. H. (2015). The effects of marketing mix on consumer satisfaction: a literature review from islamic perspectives. Turkish Journal of Islamic Economics, 2 (1), 17-30.

2. Al-Ajmi, J., Hussain, H. A. \& Al-Saleh, N. (2009). Clients of conventional and Islamic banks in Bahrain: How they choose which bank to patronize. International Journal of Social Economics, 36(11), 1086-1112.

3. Amirullah. (2002). Perilaku Konsumen. Cetakan Pertama. Graha Ilmu. Jakarta.

4. Ateba, B. B., Maredza, A., Ohei, K., Deka, P. \& Schutte, D. 2015. Marketing mix: it's role in customer satisfaction in the south African Banking retailing. Journal Banks and Bank Systems, 10(1), 83-91. 
5. Collier, D. A. (1991). A new marketing mix stresses service. Journal of Business Strategy, 12, 42-45.

6. Fajri, D.A., Arifin, Z. \& Wilopo. (2013). Pengaruh bauran pemasaran jasa terhadap keputusan menabung (Survei pada nasabah Bank Muamalat Cabang Malang). Jurnal Administrasi dan Bisnis, 6(2), 1-10.

7. Islam, F. \& Rahman, M. (2015). Service marketing mix and their impact on bank marketing performance: A case study on Janata Bank Limited Bangladesh. Journal for Worldwide Holistic Sustainable Development, 1, 16-32.

8. Kaura, V. (2013). Service marketing mix with special reference to Indian Banking. Pacific Business Review International, 6, 53-57.

9. Kustiningsih, E.W.L. (2014). Variabel-variabel yang mempengaruhi keputusan menjadi nasabah tabungan faedah Bank Bri Syariah Cabang Samarinda. E-Journal IImu Administrasi Bisnis, 2 (2), 201 -214.

10. Kotler. P. (2000). Manajemen Pemasaran. PT. Prenhallindo: Jakarta.

11. Kotler. P. (2002). Manajemen Pemasaran. Andy Yogya: Yogyakarta.

12. Malhotra, K. N. (2010). Marketing Research: An Applied Orientation, $6^{\text {th }}$ Edition. New Jersey: Pearson Education, Inc.

13. Mangkunegara. A.P. (2002). Manajemen Sumber Daya Manusia. PT. Remaja Rosda Karya: Bandung.

14. Marwan, A. (1990). Marketing Cetakan Kedua. BPFE Universitas Gajah Mada: Yogyakarta.

15. Nachrowi, D \& Usman, H. (2002). Penggunaan. Teknik Ekonometri, PT Raja Grafindo Persada, Jakarta.

16. Oke, M.O. (2012). Marketing strategies and bank performance in Nigeria: A postconsolidation analysis. Research Journal of Finance and Accounting, 3 (5), 94-102.

17. Payne, A. (1993). The Essence of Services Marketing. Prentice-Hall International Ltd., New York.

18. Roy, M. \& Khan, S. M. (2015). The impact of service marketing mixes on customer perception regarding modern banking (A study on trust bank limited, Khulna Branch). European Journal of Business and Management. 7(1), 214-221.

19. Salvatore, D. (2006). Microeconomics:theory and applications. McGraw-Hill, Inc. New York.

20. Selim, A., \& Rahman, Md. Habibur. (2015). The Effects of Marketing Mix on Consumer Satisfaction: A Literature Review from Islamic Perspectives. Turkish Journal of Islamic Economics, 2 (1), 17-30.

21. Sevilla, C. G. \& Ochave, J.A. (1960). Research Methods. Quezon City: Rex Printing Company.

22. Shamsudin, S., \& Rahman, S.S.A. (2014). The differences between islamic marketing and conventional marketing: A review of the literature. Proceeding of the $1^{\text {st }}$ International Conference on Management and Muamalah.

23. Solomon, M.R. (2002). Consumer Behavior: Buying, Having, and Being. 8th Edition. Prentice Hall: New Jersey.

24. Sumarni, M. (2002). Manajemen Pemasaran Bank. Liberti: Yogyakarta.

25. Sutisna. (2002). Perilaku Konsumen. Rosda Karya: Bandung.

26. Yupitri, E. \& Sari, R. L. (2012). Analisis faktor-faktor yang mempengaruhi non muslim menjadi nasabah Bank Syariah Mandiri di Medan. Jurnal Ekonomi dan Keuangan, 1(1), 46-60. 